\title{
Challenges of Institutional Reform in African Higher Education: the Case of Three Public Universities in East Africa
}

\author{
Philipo Lonati Sanga ${ }^{1}$ \\ ${ }^{1}$ University of Dar es Salaam [E-mail: lonati_f@yahoo.com]
}

\begin{abstract}
While globalisation has traditionally been associated with networks of commercial and political interests, today it is a challenge with which all sectors of society, including higher education, must contend. In higher education, one of its manifestations is the rapid development of borderless higher education markets. In East Africa, this has seen universities in more developed countries strategically promote their services in the region through, inter alia, for profit universities, corporate universities and distance education programmes. A direct consequence of this has been the creation of 'global students', who are not bound by the dictates of the countries in which they reside. This accelerated mobility of knowledge and skills is the impetus for the migration of skilled workers hence brain waste and brain gain. In order to examine this phenomenon more closely, three purposely-selected East African public universities perceived as more suitable examples for internationalisation and institutional reform activities were studied. These are the University of Dar es Salaam in Tanzania, Makerere University in Uganda and University of Nairobi in Kenya. The study concluded that, despite the myriad of challenges that the universities face, they have numerous opportunities. If efficiently utilised, these opportunities can help the universities to overcome their challenges. The study argues that efforts to adopt an international outlook should not derail the universities from their mandate to serve their countries.
\end{abstract}

Keywords: Institutional reform; Internationalisation; East Africa

\section{$1 \quad$ Introduction}

Globalisation has affected many aspects of our life, one of those being education. Kinyanjui (2007) and Aarts \& Greijn (2010) note that globalisation is changing the ways through which knowledge and skills are produced, disseminated and utilised. It has always been puzzling to find any agreement on what the term globalisation actually refers to or when in fact the world entered 
a global age (Morrow \& Torres in Collins \& Rhoads, 2008). Moreover, knowledge is more and more often becoming a commodity that moves between countries. The rapidly increasing demand for higher education, in turn, surpasses the capacity of many countries to provide it locally. Likewise, universities in East Africa have been directly influenced by the irresistible wave of globalisation. Since the last decade, we have witnessed transformations taking place in curriculum and general ways of doing things in many universities for the sake of improving their outlook.

Although internationalisation (for instance, see figures 1 and 2) and institutional reforms are taking place at a remarkable magnitude in Africa, little has been published on the extent to which African universities are globally competitive. Teferra and Greijn (2010) argue that, although the systems of higher education in Africa are the most marginalised in the world, there is ample evidence that they may be among the most internationalised in terms of form, dimension, and scope. The situation is partly attributed to historical, socio-political, economic, and paradigmatic factors. Most of the initiatives and reforms being made by institutions of higher education in Africa apply the DNA theory of fostering local knowledge. Cheng (2003:12) explains that this theory underlines the need to identify and transplant "the better key elements from the global knowledge to replace the existing weaker local components in the local developments." It means that fostering local knowledge is mainly a process to replace the invalid local knowledge with the relevant global knowledge through globalised education.

This idea seems to concur with Nyerere (1970)'s ideas:

... it is necessary that we should be clear in our own mind about the function of university in the modern world.... Only when we have done this can we avoid the twin dangers, on the one hand, of considering our university in the light of some mythical 'international standards', or, on the other hand of forcing our university to look inwards and isolate itself from the world in which we live.

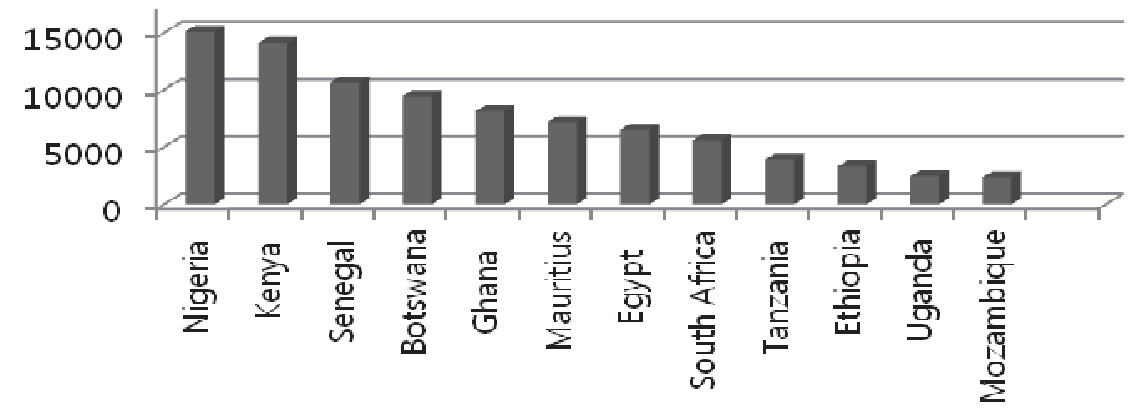

Figure 1: African University Students Studying Abroad Source: Kishun (2006) 
Figure 1 indicates that Tanzania, Uganda and Kenya are among the top twelve African countries sending students abroad for university education.

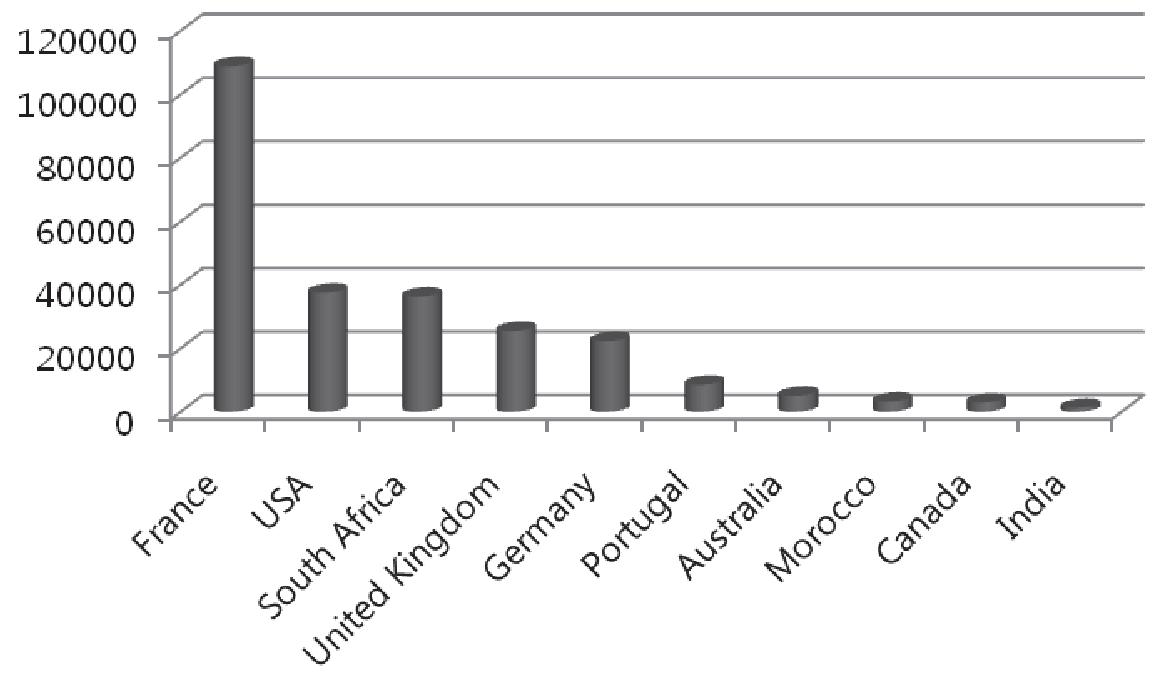

Figure 2: Top Recipients of African University Students Source: Kishun (2006)

Figure 2 shows the top ten countries where African students go for university studies abroad. Interestingly, South Africa, an African country, is third on the list, suggesting the idea that even African universities can be a top choice for Africans' university education.

Universities are transforming and consolidating aspects like teaching, research and innovation, information and communication technology application, funding, and scholarship to ensure that they produce graduates who are well equipped to tap global knowledge resources and apply their education to support local and regional development (Teferra \& Greijn, 2010; NyaigottiChacha, 2004; Sørensen, 2009).

\subsection{Purpose}

The purpose of this study was to trace the background of higher education institutional reforms in East Africa and point out the challenges they face in the era of globalisation. Towards this end, the specific objectives were to:

- Trace the setting of East African public universities reforms,

- Display the priority activities undertaken for internationalisation, and

- Outline the challenges that these universities face in this era. 


\subsection{Role of Higher Education in Africa}

Despite the fact that higher education may be defined differently in other studies, this paper consistently refers to it as post-high school education obtained from institutions of higher learning, especially universities. In order to connect to the "global knowledge backbone" (Bon, 2010, p. 63), any university ought to fully discharge the conventional tripartite functions expected of them: teaching, research, and consultancy. Higher education contributes to socioeconomic development through, inter alia, production of a highly skilled workforce, increasing labour mobility, facilitating the labour force's capacity to absorb new technology, knowledge, and skills, removing socio-cultural barriers to development, and promoting entrepreneurship.

In general, higher education graduates are likely to be more conscious of and better able to apply new technologies in various sectors of the economy. Thus, in a knowledge economy higher education can help economies keep up or catch up with more technologically advanced societies. Moreover, one critical role of higher education is to create learning environments that enhance students' abilities to make sense of their world in ways that enable them to change it for the better, for themselves and others, and to equally allocate "life chances" (Marginson, 1999, p.28). Education has to provide academic skills that engage students in understanding and applying various sorts of knowledge, critically and analytically, and social skills that cultivate consciousness of their citizenship and civic participation. This view is supported in Nguyen(2006)'s analysis of higher education and globalisation that instead of solely certifying students' knowledge with academic degrees and titles, the ultimate goal of higher education should be to provide benefits to society by training innovative, informed, and responsive workers who also possess cultural tolerance and understanding. Therefore, as suggested by Meulemeester \& Rochat (1995), it is vital that the social, political, and economic structures and the technological level of the society to which the education system belongs are such that graduates can actually make use of their accumulated knowledge for sustainable socio-economic development of their communities.

As a repercussion of globalisation, all people are literally competing with everyone, from everywhere, for everything. And everything means the entire world's resources and markets. Everyone seems to be trying to grab the same things that everyone else wants, particularly the most precious and limited things: “ . . . knowledge, capabilities, and, most importantly, people: leaders, managers, workers, partners, and, collaborators ..." (Sirkin, Hemerling \& Bhattacharya, 2008, p. 3). Globalisation necessitates neither equity, nor homogenisation. Under these circumstances, this knowledge-based competition within globalisation, institutions of higher learning are prompted to reconsider their role in socio-economic development. 


\subsection{Context and Status of Higher Education in East Africa}

The history of higher education in East Africa can be traced back to 1922 when Uganda Technical School, later renamed Uganda Technical College, was established. In 1937, the college expanded into an institution of higher education before it became a University College of the University of London in 1949 (Makerere University, 2010). Afterwards, it became a college for the whole of East Africa, offering courses which led to awards and distinctions. Until the early 1950s, it was the only college providing university education in East Africa. In 1956 the Royal Technical College was established in Nairobi, Kenya. Then, in 1963, the Royal Technical College became the University College, Nairobi following the establishment of the University of East Africa with three constituent colleges in Nairobi, Dar es Salaam, and Kampala (Nyaigotti-Chacha, 2004). In Tanzania, up until the time of independence from British colonialism in 1961, there were no universities available locally. Africanising the workforce became the main challenge of nationalistic leadership, hence the establishment of the University College Dar es Salaam as a college of the University of London with fourteen students. It became a constituent college of the University of East Africa in 1963 (University of Dar es Salaam [UDSM], 2011). The University of East Africa offered programmes and degrees from the University of London until 1966. The dissolution of the University of East Africa in 1970 led to the creation of the three first autonomous public Universities of Dar es Salaam (UDSM), Makerere, and Nairobi in Tanzania, Uganda, and Kenya, respectively (UDSM, 2011).

East African countries are increasingly becoming cognisant of the principle that the capacity to assimilate knowledge, especially that knowledge attainable from higher education, is a key factor in any nation's struggle to catch up in all aspects of socio-economic development. The manifest expansion of the higher education sector seems to be inexorable in all of these countries. Table 1 below shows the number of universities in each country and their total student enrolment for the academic year 2009/10.

Table 1: Number of Universities in East Africa (2012)

\begin{tabular}{llll}
\hline & Tanzania & Uganda & Kenya \\
\hline Public universities & 8 & 5 & 7 \\
Private universities & 20 & 28 & 23 \\
Total number of universities & 28 & 33 & 30 \\
Approximate enrolment & 140,000 & $92,605^{*}$ & 140,000 \\
\hline
\end{tabular}

*Data available is for the academic year 2008/09

Sources: UDSM (2011); University of Nairobi (nd); Makerere University Fact Book (2011). 


\section{$2 \quad$ Methodology}

This paper draws conclusions from analysis of data from primary and secondary documents belonging to the three oldest public universities in East Africa: The University of Dar es Salaam (Tanzania), Makerere University (Uganda), and the University of Nairobi (Kenya). These three are not necessarily representative of all public universities in East Africa but they possess many common characteristics and a shared history which render them key icons of higher education within the region. Up until data collection for this study began, these three universities were the oldest, largest, and most reputable public universities in their respective countries. Information about the background and priority activities of the institutions was chiefly obtained from the documentary analysis of the institutions' comprehensive strategic plans. Institution's websites and other documents supplemented the data needed for this study.

Analysis of literature from some textbooks and articles related to the history and reforms of the institutions was conducted to extract information pertinent to the current study. Selection of these documents was primarily based on the validity and reliability of the information. The information extracted was confirmed by analysing several sources for the same issue. Further, a structured questionnaire was administered to three staff in charge of institutional policy and planning for each of the three institutions. Information obtained from these nine questionnaires served the purpose of giving data for the three objectives of this study, especially the third one. Equally important, questionnaire responses could help to validate certain documentary information. Data obtained from all sources were sorted out and put into four themes: institutional setting of reforms, priority activities for internationalisation, institutional challenges, and other emerging issues related to institutional reforms. Each theme was closely analysed in relation to the objectives of the present study, and it was handled predominantly qualitatively.

\section{$3 \quad$ Setting of University Reforms in East Africa}

Many authors posit that the globalisation of higher education is linked to both various internal and external forces (Chinnamai, 2005). Approached differently, Chan (2004) and Haigh (2008) outline economic, academic, and socio-cultural drives to this phenomenon. While it is apparent there are many and diverse forces behind the globalisation of higher education, De Wit (2002) perceives that different institutions, stakeholders, and groups of individuals do not have a single exclusive reason for that trend. 
Major reforms at the University of Dar es Salaam (UDSM) came at the same time as reforms in Tanzania's banking and financial sectors which had been mandated by the International Monetary Fund (IMF). Luhanga, cited in Bollag (2004, p.7), reveals that some people wrongly perceived that UDSM's reforms had also been mandated by the IMF. The 1980s global economic crisis left the University of Dar es Salaam with diminished government financial support. Luhanga further states that amid the darkness, the Faculty of Engineering searched for a new pathway. Due to factors including the low salaries of engineering academicians as compared to their counterparts employed in other sectors, it was this faculty which lost the most academic staff. Responding to this challenge, the Faculty of Engineering pioneered a series of reforms whose first step was to establish a Bureau for Industrial Cooperation (BICO) to promote consulting work and allow faculty members and their departments to earn extra money.

It was later thought necessary to replicate this model within the entire university. The first draft of this institutional strategic plan was presented in 1992 to a meeting of the university community and foreign donor organisations. This yielded a final publication of the Corporate Strategic Plan (CSP) in 1994 which has been the basic guide for the university's transformation. The plan plainly states that the university's mission must adapt to meet the profound changes taking place within the country. However, faced with a collapsing economy and pressure from global lending organisations, the government opened up the economy to private ownership and foreign investment. Therefore, the changing labour market required the university curricula to produce graduates with skills different from those traditionally offered. In response to the observed constraints and considering the current and new developments, nationally and globally, the university reviewed the CSP in 2003 to cover the period 2004-2014. The main focus areas of CSP 2004-2014 are to ensure capacity development, quality assurance, and outreach activities by closely reflecting upon the university's vision, mission, and its core functions (UDSM, 2011). The genesis of UDSM's reforms can be considered to be an example of a top-down revolution (Luhanga, 2003).

The reforms of the University of Nairobi were very much influenced by the Public University Inspection Board report which prompted all universities in Kenya to undergo a transformation to be compatible with the developmental and entrepreneurial qualities of the $21^{\text {st }}$ century and address many issues including the increasing demand for access and equity. The paradigm shift involved a transformation of higher education for combating national problems and tackling global challenges. It is with this understanding that the University of Nairobi had to review the strategic plan of 2005-2010 and recast it to 2013 (University of Nairobi Strategic Plan, 2008-2013). The university was therefore 
obliged to plan a new strategic direction while at the same time being increasingly aware of the importance of its position in a global community.

The institutional transformation of Makerere University is referred to as "a quiet revolution" by some authors (Makerere University, 2000, p. ii). Makerere University's institutional reform was essentially an implementation of alterative financial strategies as a response to the government's reduced commitment in financing higher education (Kwesiga \& Ahikire, 2006). The university had to envision being market-oriented and one means to this path was the introduction of the private sponsorship programme in 1992 which significantly stretched the intake of fee-paying students. About seven years later, Makerere had leaped from a position of one where nobody paid fees to one where $80 \%$ of students paid fees, accounting for more than $50 \%$ of the university's total revenue. Emphasis on a private sponsorship programme notwithstanding, enrolment at Makerere University has been burgeoning yearly. Currently, the university is profoundly dominated by privately sponsored students (see Figure 4). Due to a public outcry that massive enrolment numbers are harmful to the quality of education, the Uganda National Council for Higher Education (NCHE) resorted to implementing student admissions ceilings for all programmes and to all universities within the country (Makerere University, 2010).

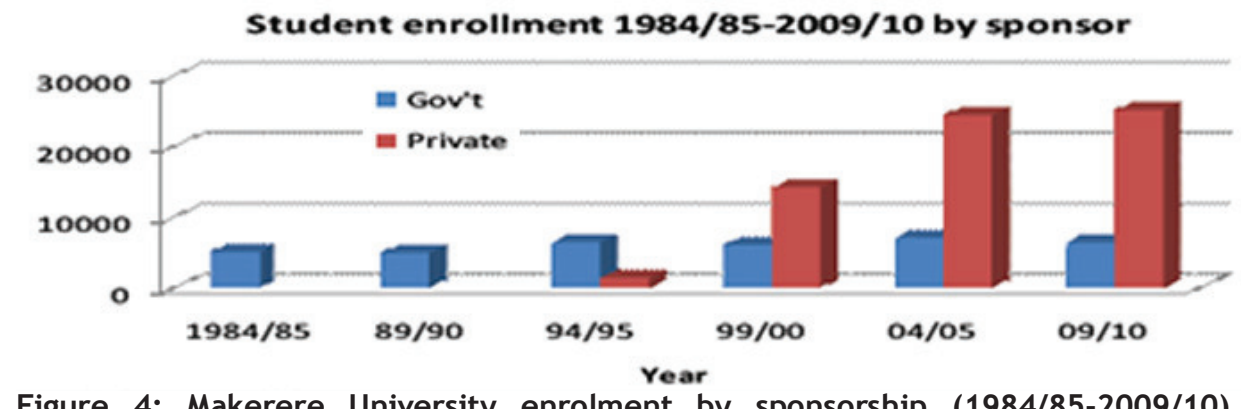

Figure 4: Makerere University enrolment by sponsorship (1984/85-2009/10). Source: Adopted from Makerere University Fact Book (2011, p.11).

Analysis of these institutions' background for educational reforms suggests that their decisions to undertake institutional reforms were driven by different motives. Carnoy (1999) proposes three categories of reforms. The University of Dar es Salaam's reforms conform more to characteristics of competitivenessdriven reforms. These reforms focus on improving productivity, the quality of the "human factor" (Organisation for Economic Co-operation and Development, in Carnoy, 1999, p.37), and of the institution. Strategies to achieve competitiveness include decentralisation, quality assurance, improved management of institutional resources, and development of academic staff recruitment and training. The University of Nairobi experienced equity-driven reforms whose philosophy is to increase equality through increasing 
accessibility to education. Ostensibly, Makerere University's interpretation of globalisation is increasing competition among institutions and nations in a more knotted, international economy, hence finance-driven reforms.

\section{$4 \quad$ Priority Activities for Internationalisation}

The strategic choice to address the implications of globalisation appeared to differ somehow in terms of scale of preference among these East African universities. Hereunder is the summary for the main priority activities of each university.

Table 2: Top Priority Activities for Internationalisation

\begin{tabular}{|c|c|c|}
\hline University of Dar es Salaam & University of Nairobi & University \\
\hline $\begin{array}{l}\text { - } \quad \text { Curricular reforms to } \\
\text { encourage entrepreneurship } \\
\text { skills. } \\
\text { Optimising the use of all the } \\
\text { institution's resources } \\
\text { through expansion of student } \\
\text { enrolment to optimise the } \\
\text { formerly overstaffed } \\
\text { university and widening } \\
\text { access to university } \\
\text { education, } \\
\text { Upgrading Advanced } \\
\text { Information and } \\
\text { Communication Technology } \\
\text { (ICT) infrastructure and } \\
\text { enhancing information } \\
\text { systems, } \\
\text { Increasing academic support } \\
\text { through converting } \\
\text { traditional teaching/ } \\
\text { learning materials into } \\
\text { electronic format, enhancing } \\
\text { instructional technology } \\
\text { resources (software \& } \\
\text { hardware), and promoting e- } \\
\text { Learning initiatives, and } \\
\text { General staff development } \\
\text { to improve the quality of } \\
\text { education. } \\
\text { (Source: University of Dar es } \\
\text { Salaam Revised Corporate } \\
\text { Strategic Plan, 2004-2014) }\end{array}$ & 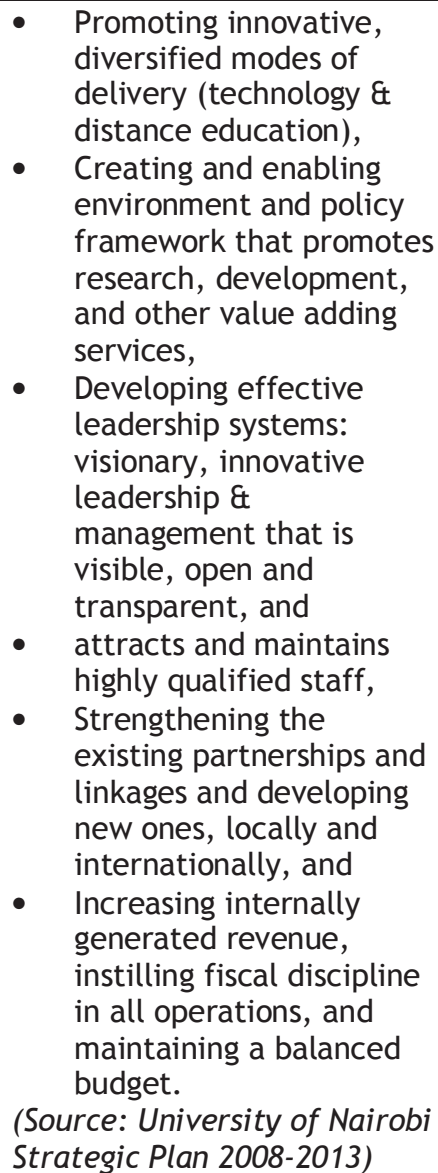 & $\begin{array}{ll}\text { - } & \text { Diversifying } \\
\text { income } \\
\text { - } \quad \text { generation } \\
\text { sources, } \\
\text { - } \quad \text { Investing in E- } \\
\text { Learning } \\
\text { - } \quad \text { systems, } \\
\text { - } \quad \text { Engaging in } \\
\text { International } \\
\text { - } \quad \text { artnerships } \\
\text { and distance } \\
\text { education, } \\
\text { - } \quad \text { Boosting quality } \\
\text { assurance } \\
\text { in order to } \\
\text { become } \\
\text { - internationally } \\
\text { competitive, } \\
\text { and } \\
\text { Expanding } \\
\text { capacity in } \\
\text { medical, } \\
\text { technology, and } \\
\text { Science } \\
\text { education. } \\
\text { (Source: Makerere } \\
\text { University Strategic } \\
\text { Plan 2008/09 - } \\
\text { 2018/2019) }\end{array}$ \\
\hline
\end{tabular}


The activities and strategies opted by these universities may directly reflect the aspects of internationalisation which are principally emphasised by each university. For example, the University of Dar es Salaam's competitivenessdriven reforms focus most on transforming the curriculum, above all, to prepare students with entrepreneurial knowledge and skills and on upgrading ICT infrastructure. In this way, students are prepared to be globally competitive not only academically but also socially and technologically. The University of Nairobi's equity-driven reforms focus chiefly on implementing innovative academic curriculum but with a special emphasis on fostering a flourishing environment for research. Makerere University's concentration is on income generation and expanding horizons for international partnership. Finance-driven reforms have made it possible for this institution to be an exemplary model in attracting privately-sponsored students, of which 50 per cent of the university's revenue is generated. Differences in priority strategies for globalisation may not necessarily be a fundamental reason for variation in the speed and nature of growth among institutions, but rather, may be a result of the firmness and consistency the institution employs to implement its priority strategies.

\section{$5 \quad$ Most Challenging Issues}

There are many challenges that universities in East Africa face as they struggle within the era of globalisation. These challenges mitigate the institutions' commitment to maximising their potential in realising their missions and goals. While these universities certainly face many challenges, this study unveiled the following to be the primary hurdles.

\subsection{Massification of Higher Education}

In regards to East African universities, UNESCO's basic Education for All movement (Jomtien, 1990) appears to have induced a higher education for all fallacy. In this paper, massification refers to the increase in student enrolment in higher education institutions (Mohamedbhai, 2008). This phenomenon directly induces a sharp increase in the number of institutions, as well as fundamentally different types of institutions, as the diverse needs of students become "reflected in the programmatic and institutional structures of the system" (Gumport, 1997, p.2). Most of these universities, especially private ones in Tanzania, Kenya, and Uganda, have mushroomed in size within the last decade. While the use of national enrolment ratios or participation rates may be appropriate to define massification of higher education in heavily industrialised countries, this may not necessarily be the case for less industrialised countries, like those sampled in this study. These countries have a very low higher 
education enrolment to population ratio but they have experienced a very rapid increase in actual numbers of students enrolled in higher education within the last decade.

Accommodating large numbers of students wishing to access higher education in East African countries is imperative, which is why these three universities are critically overcrowded just like other public universities in the region. Poor planning coupled with a meagre supply of resources tends to exacerbate the problem of overcrowding. In Kenya, the admissions crisis had existed for decades and caused a backlog that had forced students accepted to the university to wait for two years before they could be admitted for studies. Recently, the government of Kenya has called for an end to the long wait through a double intake plan, admitting over 8,000 more students in 2011 than in the previous year (Ndanyi 2011).

Undesirable effects of massification notwithstanding, there are desirable effects too. For instance, by and large, massification is a good vehicle for widening access to higher education because one of the greatest needs of these countries is highly skilled and resourceful human capital to push forward the national development agendas. The belief is that quantity yields quality in the long run.

Furthermore, establishing and nurturing a truly competitive university calls for a direct involvement of national governments through practical policy intervention and financing. Although there are certainly many paths towards this effect, a choice may be required to be made from at least three preconditions as put otherwise by Liu, et al. (2011). Firstly, consider upgrading a small number of existing universities that have the potential for outshining others. Secondly, encourage a number of existing institutions to synergise. Thirdly, create new competitive universities from scratch. Each option has strengths and weaknesses which must be weighed accordingly.

\subsection{University Autonomy}

This study revealed that these three universities share a common cry for autonomy and academic freedom. Omari (1991) describes university autonomy as the extent of the proximity of the state to the university. University autonomy can be referred to as the freedom given to universities and manifested in processes such as governing themselves, appointing key staffs, determining the conditions of service of their staff, controlling their students, admissions, and academic curricula, controlling their finances, and generally regulating themselves as independent legal entities without unnecessary interference from the government and its organisations. Further, Mazrui, cited in Omari (1991), decries the proximity between the universities and the national structure of power which in African situations has tended to curtail academic 
freedom and consequently, intellectual expansion among students and staff. For example, there have been reported cases of serious government encroachment on university recruitment and contract renewal of professors (University of Dar es Salaam), university budget and spending (Makerere University), and curriculum and timetables (University of Nairobi) as it can be reflected from the excerpt below:

From now on, the University of Nairobi will be answerable to the government and to the ruling party. . . . I do not want to hear any more demands for such a thing as academic freedom. Who will give you academic freedom? Who pays your salary? Even at Cambridge, there is no such thing as academic freedom. Because the government pays it, they do what the government wants. What are you going to do with this academic freedom that you people of the University of Nairobi are calling for? (Former President of Kenya, Moi, cited in Chege, 2006).

In view of this paper, education is a political enterprise; accordingly, government intervention is absolutely justifiable and should be skilfully undertaken. What is worthy of cautioning here is not the involvement of the government per se, but rather the extent and manner of the interferences. It is neither feasible nor justifiable that any sensible government does not take part in its universities' affairs. With all these factors in mind, university autonomy is a necessity for achieving excellence. But, this alone is not a sufficient condition. Limitation to autonomy in terms of accountability to the state and other stakeholders is indispensable to ensure these universities' good governance.

The challenge regarding the university autonomy has always been in terms of how to position itself amongst the three strong categories of forces: professional, government, and market forces as portrayed by Clark's triangle (See Figure 5 below). Again, Tudiver (1999) warns:

Universities driven by market priorities provide a limited contribution to democratic processes. They cannot foster the kind of debate and social criticism that thrives in an independent academy (Readings, 1996). The university is supposed to be a forum for open debate from all perspectives ( $p$. 189).

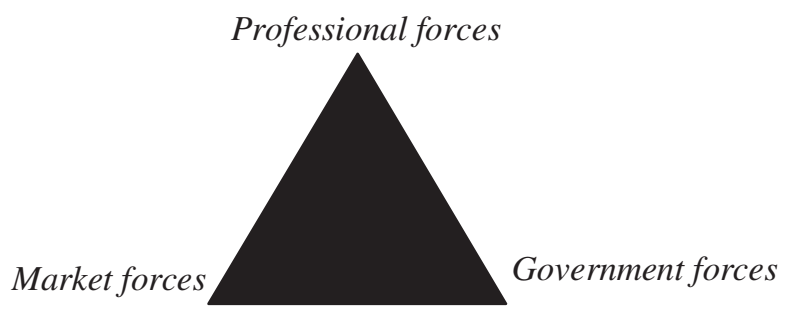

Figure 5: Clark's Triangle for Forces Affecting University Autonomy 


\subsection{Challenges Related to Emerging Technologies}

Advanced Information and Communication Technologies (ICTs) hardware and software are still yet to be effectively exploited by these universities. For instance, there is an inadequate number of computing facilities (computers, printers, photocopiers, and scanners) in students' public access rooms. Although these institutions are better internet-connected compared to most public and private universities in their respective countries, the reliability of and access to them is daunting. In most cases, the campus buildings have a low capacity for these technologies, an obsolete backbone network infrastructure, and poor or unstructured Local Area Network (LAN). Similarly, Wireless Local Area Networks (WLAN), which is one among the many appropriate options for generating better technologies at these institutions, is seldom put to use. The National Networked Readiness Indexes (NRI) equally influences these institutions' extent of access to ICTs. The table below (Table 3) indicates that Kenya is ahead of Tanzania and Uganda in terms of access to ICTs.

Table 3: National Networked Readiness Index (NRI) of East African Countries

\begin{tabular}{lllllll}
\hline Country & $\begin{array}{l}\text { NRI } \\
\text { global } \\
\text { ranking }\end{array}$ & $\begin{array}{l}\text { Population } \\
\text { (in }\end{array}$ & $\begin{array}{l}\text { GDP per Internet } \\
\text { capita } \\
\text { (USD) }\end{array}$ & $\begin{array}{l}\text { Insers (per } \\
\text { 100 people) }\end{array}$ & $\begin{array}{l}\text { Bandwidth } \\
\text { (Mbps/10,000 } \\
\text { people) }\end{array}$ & Teledensity \\
\hline Kenva & 97 & 37.5 & 580 & 8 & 0.2 & 30.5 \\
Tanzania & 119 & 40.4 & 350 & 1 & 0 & 20.4 \\
Uganda & 120 & 30.9 & 300 & 6.5 & 0.1 & 13.6 \\
\hline
\end{tabular}

Source: Bon (2010: 70)

Advanced ICTs are imperative for universities to discharge their functions more competitively in this digital era. Although one could expect all university classrooms and learning venues to be at least internet connected, the situation is such that very few classrooms are outfitted with such technologies, even in the most prestigious universities in the region. As such, common synchronous technologies like videoconferencing and web conferencing on one hand, and asynchronous technologies like discussion forums, Google, and wiki searching on the other hand, are quite rarely promoted within the classroom setting. In spite of the clear opportunities related to ICTs that these universities have, there is still a lack of real awareness about the benefits of ICTs as a result of biased mind sets, an unwillingness to face the technological changes occurring in universities, and a lack of a clear perception as to how ICT resources can be sustainably managed.

\subsection{The Paradox of Internationalisation}

While all these East African universities would confidently declare to be effectively implementing internationalisation strategies, this study revealed that 
in most cases there is actually more localisation and regionalisation than internationalisation. For instance, regarding enrolment of international students, Makerere University admitted 1,135 foreign students in 2010/11 (3.4\% of total enrolment) out of which 1,023 (90\%) came from Kenya and 88 students (7.8\%) from Tanzania. Only 3 students enrolled at Makerere in 2010/2011 were nonAfrican nationalities. The average percentage of international students being admitted at the University of Dar es Salaam for the period 2005-2010 was $3.5 \%$, of which, similarly, was comprised mostly of students who hailed from East African countries. It can be argued that these 'international' students are not international in a strict sense, but rather 'regional' students.

Literature, however, suggests that this may be the trend of many institutions worldwide. For example, reviews of studies for two Asian national (public) universities which are regularly within the top 50 world universities corroborate this finding. Out of 28,017 students enrolled at the University of Tokyo in Japan in 20112,540 (9.1\%) were international students (The University of Tokyo, 2011). Among these international students, $1,678(66.1 \%)$ are from nearby China and Korea. Analysed otherwise, 2,443 international students (96.2\%) out of the total 2,540 international students at Tokyo University came from other Asian countries. Although the readily available statistics for Seoul National University in Korea (SNU) did not provide a breakdown of the composition of international students, a simple observation proposes that it is not an exception. Of the total enrolment of 28,018 students in 2011 at SNU, a mere 2,486 students (8.9\%) were international students (Seoul National University, 2011).

It is thus most likely that in many universities, globally 'international' students are actually 'regional' students from the closest neighbouring countries regardless of the way the institution may try to express its outlook. There is a potential for synergy between internationalisation and regionalisation of higher education but one can just as well limit the success of the other depending on their focus. In these universities, internationalisation has mainly involved new forms of providing higher education to students, but sometimes without necessarily being of relevant curriculum to suit local needs. Concurrently, regional approaches in the context of broader Pan-Africanism on the implications of internationalisation on the continent are being implemented. As such, internationalisation in these universities poses numerous questions in relation to the extent and intensity of their capability to address local and regional access, equity, research, and development agendas.

There is, yet one issue seemingly unresolved, institutions, including universities, are usually encouraged both to cooperate and compete with each other. However, in business spheres there is a paradox of cooperation and competition. How can the two exist concurrently? Unless the institutional 
leadership is flexible and prudent enough, balancing cooperation and competition becomes a truly tricky task.

\subsection{Students' Welfare}

It has been established that these institutions are constantly challenged by student strikes which appear to be recurring annually for a decade now. In 2011 alone both Makerere and Dar es Salaam universities experienced their students going on strike at various times. Nairobi University witnessed their academic staffs' strike in 2011 and their most recent student strike in 2010. The persistent student strikes are, by and large, one key symbol of student welfare anomalies. Every time students go on strike they express to the respective authorities their desire for ultimate solutions. Normally, going on strike is said to be the last resort after having used all other traditional bureaucracies to express their demands. Despite the costs in terms of time, destruction and loss of property, injuries, and even deaths of innocent individuals, ample evidence confirms that these strikes have ended with authorities' positive responses to the students' demands.

Student strikes are repeatedly associated with rising tuition fees, biased Students' Loans Board procedures, poor housing and sanitation facilities, and dissatisfaction with general learning conditions on campus. Although student welfare is a critical component of any university planning, it is often overlooked in some university planning agendas. Some educators and administrators tend to deliberately bypass issues directly related to student welfare. For instance, despite the good motive of recommendations such as: "the admission of students to state universities should be de-linked from bed spaces, but be linked to availability of academic and tuition facilities," as summarised by Kinyanjui (2007), are criticised right away. Housing problems are among the key sources of student frustrations, thus, leaving the task of hunting for housing on students themselves. This is seriously risky, particularly when one considers the complexities and exorbitant expenses involved in searching for accommodations near these urban universities. Most importantly, the majority of private housing facilities and transportation to and from the campus are of very poor quality and unsafe. To promote universities which can effectively compete in this era of globalisation, institutional and national policy makers have to consider students as major partners and responsible stakeholders in the process of policy making.

\section{Opportunities for East African Universities}

- Growing recognition of the role of higher education in national development. National governments in East Africa are rapidly 
acknowledging the critical contribution of higher education to socioeconomic development plans.

- Institutional internationalisation strategies. The increasing admission of foreign students, academic staff collaboration in research, and numerous international conferences foster cross-fertilisation of ideas.

- Strategies and innovative use of ICT and access to fast broadband internet. Innovative use of ICTs boosts international research activities and improves the local publishing infrastructure.

- Stable collaboration with global development partners. These universities enjoy long-term stable partnership and strategic development assistance from many reliable global partners such as the Africa Institute for Capacity Development (AICAD), Lake Victoria Basin Research Initiative, Norwegian Agency for Development Cooperation (NORAD), Swedish Sida/ Sarec, and the Carnegie Corporation.

\section{References}

Aarts, H. and Greijn, H. (2010). Globalisation, knowledge and learning: Developing the capacities of higher education institutes. In D. Teferra \& H. Greijn (Eds.), Higher education and globalisation, challenges, threats and opportunities for Africa (pp. 63-77). Maastricht: MUNDO.

Bollag, B. (Ed.) (2004). Improving Tertiary Education in Sub-Saharan Africa: Things that Work. Report of a regional training conference, Africa Region Human Development Working Paper Series.

Bon, A. (2010). Information and communication technologies in tertiary education in Sub-Saharan Africa. In D. Teferra \& H. Greijn (Eds.), Higher education and globalisation, challenges, threats and opportunities for Africa (pp. 63-77). Maastricht: MUNDO.

Carnoy, M. (1999). Globalisation and educational reform: what planners need to know. Paris: UNESCO.

Chan, W.Y. (2004). International cooperation in higher education: theory and practice. Journal of Studies in International Education, 8:32-55.

Chege, M. (2006). The state of higher education in Kenya: problems and prospects. Paper Presented at the Mijadala on Social Policy, Governance and Development in Kenya' sponsored by Development Policy Management Forum at Nairobi Safari Club, Nairobi, Kenya.

Cheng, Y. C. (2003). Local knowledge and human development in globalisation of education. International conference on globalisation and challenges for education. New Delhi: NIEPA. 
Chinnamai, S. (2005). Effects of globalisation on education and culture. ICDE International Conference, New Delhi.

Collins, C.S. and Rhoads, R.A. (2008). The World Bank and higher education in the developing world: The cases of Uganda and Thailand. The Worldwide Transformation of Higher Education International Perspectives on Education and Society, 9, 177-221.

Meulemeester, J. And Rochat, D. (1995). A causality analysis of the link between higher education and economic development. Economics of Education, (14) 4,251-361.

De Wit, H. (2002). Internationalisation of higher education in the United States of America and Europe: A historical, comparative, and conceptual analysis. Westport, Connecticut: Greenwood Press.

Gumport, P.J. et al. (1997). Trends in United States higher education from massification to post massification. Stanford University: National Centre for Post secondary Improvement.

Haigh, M. (2008). Internationalisation, planetary citizenship and higher education. Compare, 38 (4), 427-440. http://www.eac.int/ retrieved on February 12, 2012.

Kinyanjui, K. (2007). The transformation of higher education in Kenya: challenges and opportunities. Paper presented at the Mijadala on Social Policy, Governance and Development in Kenya sponsored by Development Policy Management Forum, Nairobi Safari Club, Nairobi, Kenya.

Kishun, R. (2006). Introduction: The internationalisation of higher education in South Africa: Progress and challenges. In R. Kishun (Ed.) The internationalisation of higher education in South Africa (pp. 1-12). Durban, South Africa: Astro Printers International Education Association of South Africa.

Kwesiga, J.C. \& Ahikire, J. (2006). On student access and equity in a reforming university: Makerere in the 1990s and beyond. JHEA/RESA, 4 (2), 1-46.

Liu, N. C. et al. (Eds.). (2011). Paths to a world-class university, lessons from practices and experiences. Rotterdam. Sense Publishers.

Luhanga, M. (2003). Higher education reforms in Africa: the University of Dar es Salaam experience. Dar es Salaam: Dar es Salaam University Press.

Makerere University Fact Book (2011). Retrieved March 22, 2012 from http://mak.ac.ug/about/facts-figures/enrolment.

Makerere University (2000). Strategic plan 2000/01-2004/05. Planning and Development Department: Kampala

Makerere University (2010). ICT Policy/Master Plan (2010 - 2014). Kampala: Makerere University

Marginson, S. (1999). After globalisation: emerging politics of education. Journal of Educational Policy, 14 (1), 19-31. 
Mohamedbhai, G. (2008). The effects of massification on higher education in Africa. Consultancy report to ADEA. Retrieved October 17, 2011 from http://www2.aau.org/wghe/scm/meetings/mai08/adea/study_massification.pd f.

Ndanyi, M. (2011, June 22). UASU faults double-intake plan in universities. The Star. Retrieved March 22, 2012 from http://www.the-star.co.ke.

Nguyen, C.H. (2006). Brain drain or brain gain? The revitalisation of slow death. Retrieved October 5, 2011 from http://www.usca.edu.

Nyaigotti-Chacha, C. (2004). Reforming higher education in Kenya challenges, lessons and opportunities. Paper presented at the workshop for Parliamentary Committee on Education, Science and Technology, State University of New York, Naivasha, Kenya.

Nyerere, J.K. (1970, August). Relevance and Dar es Salaam University. Inaugural speech presented at the University of Dar es Salaam. Dar es Salaam, Tanzania.

Omari, I. (1991). Higher education at crossroads in Africa. Nairobi: Man Graphics Limited.

Seoul National University (2011).Seoul National University. Retrieved February 2, 2012 from http://en.snu.ac.kr.

Sirkin, H.L., Hemerling, J.W. \& Bhattacharya, A. K. (2008). Globality: competing with everyone from everywhere for everything. New York: Business Plus.

Sørensen, A. (2009). Internationalisation of higher education and research: The Case of SANORD, Final Report. Danish Development Research Network.

Teferra, D. \& Greijn, H. (Eds.), Higher education and globalisation, challenges, threats and opportunities for Africa. Maastricht: MUNDO.

The University of Tokyo (2011). The University of Tokyo. Retrieved February 2, 2012 from http://www.u-tokyo.ac.jp.

Tudiver, N. (1999). Universities for sale: resisting corporate control over Canadian higher education. Toronto: Canadian Association of University Teachers.

University of Dar es Salaam [UDSM] (2011). Facts and figures 2009/2010. Dar es Salaam: UDSM.

University of Dar es Salaam [UDSM] (2011). Revised corporate strategic plan, 2004-2013). Dar es Salaam: UDSM.

University of Nairobi (nd). Strategic Plan 2008-2013. Nairobi: University of Nairobi. 